\title{
From Maoist Self-Reliance to International Oil Consumer: A Resource-Based Appraisal of the Challenges Facing China's Petrochemical Sector
}

\section{Damian Tobin}

Department of Finance \& Management Studies (DeFiMS), School of Oriental \& African Studies (SOAS), University of London.

Address for Correspondence: Dr. Damian Tobin, DeFiMS, SOAS, University of London, Thornhaugh Street, Russell Square, London WC1H 0XG, United Kingdom. Phone: +44 207898 4058. Fax: +44 207898 4089. Email: dt29@soas.ac.uk

(This version: December 2007)

\begin{abstract}
Resource-based theories of the firm argue that the success of one firm over another is largely due to its resource endowments. Large enterprises have long been recognised as leading sources of learning innovation and growth. This is not just restricted to large firms in developed economies, but also applies to firms in developing economies like China, where large firms have long and complex histories in the state bureaucracy. Focusing on the case of China's petrochemical sector, this paper argues that even is a sector with a long history in central planning, the critical resources of a firm matter. It shows how existing organisational resources inherited from the pre-reform era, when provided with the correct incentive structures, can survive economic transition and be successfully applied under market conditions. In the petrochemical sector a key inducement was the commitment of the state to expose the sector to international developments where possible. The paper describes how this commitment has resulted in a mostly positive adjustment, but has also created ambiguities over how resources should be developed in future in a rapidly changing global industry.
\end{abstract}

Keywords: Critical Resources, Firm Theory, Petrochemicals, Oil, China JEL: D23, L33, L71, P31, P45.

Word Count: 9,618 (including notes, references, figures and tables)

Acknowledgement: The author would like to thank Pauline Loong, Leo F. Goodstadt, Stuart Chiron, Ashley Alder, David Li, Mathew Yiu, Roger Luk, Simon Ogus, and Steven Green for their assistance with various aspects of the research fieldwork and Laixiang Sun and Christopher Howe for helpful suggestions. 


\section{Introduction}

The literatures on corporate governance and financial globalisation have suggested few benefits for developing economies in the absence of full capital account liberalisation and convergence with international institutional standards (La Porta et al, 2000; Kose et al, 2007). Yet within these literatures little attention has been given to the adaptive qualities of large firms in developing countries, particularly how they apply critical resources to overcome constraints to development, even when the institutional thresholds deemed necessary for development are only partially met? Similarly, limited effort has been put into developing analytical perspectives on the role of large enterprises in developing economies (Singh; 1995). This is despite the fact that large firms have traditionally played a role in economic development, driving innovation and benefiting from economies of scale (Schumpeter 1928, Chandler, 1990). This paper illustrates how the critical resources of large firms, even in developing economies such as China, can be applied to overcome constraints in strategically sensitive industries such as petrochemicals. By 2005, China state-owned refineries controlled over $7 \%$ of the world's refining capacity, second only to the United States. However the significance of the sector lies not just in its size and long connection with central planning, but also the early commitment by the state that the sector should as far as possible reflect international practices.

Resource-based theories of the firm argue that the success of one firm over another is due, in a large part, to its resource endowments. Nolan (1998) argues that the success of big business, whether in China or in developed western economies lie in complex episodes of business history relating to the firms special characteristics. As part of China's oil industry, the petrochemical sector has a long history as a strategically important supplier of raw materials for China's industrial enterprises. Mao Tse-tung identified it as one of China's strategic industries. Daqing oil field, one of China's most famous industrial models in the Mao era, was intended to serve as a model of production for the rest of the economy. It was one of the first industries to receive substantial quantities of imported technology. These early resource endowments gave the sector a significant early advantage and contributed to the dramatic increases in production during the 1960s and China's emergence as a netexporter of oil. However, the failure to discover new reserves of sufficient quality and burgeoning domestic demand for petroleum products meant that such ideological concepts as self-reliance and voluntarism were no longer appropriate to China's 
development model. Yet, early liberalisation also forced the sector to become one of the most reformed state industries by the mid-1990s. More remarkable is that rather than introducing private firms or new management, the sector retained the strong organisational cultures and resources from the pre-reform era, and applied them under market conditions.

The development of the sector suggests that existing resources can be exposed to and modified by market experiences. This type of development is more consistent with production models that emphasise the accumulation of skills and fixed assets to advance production opportunities, favoured by historians of Japanese and American development (Rawski, 1975). Within this framework, large firms and their ability to promote learning and adaptation are key features. Learning can come from many sources, creates opportunities and threats, and is not restricted to achieving institutional convergence. For example financial globalisation can play a role in mitigating the financing constraints of firms by creating opportunities for international fund raising and integrating international practices. It can also create ambiguity over how enterprise management should learn and adapt. In China reforms created ambiguities as to how management were to behave under the market system or indeed how they could be trained to do so (Hsu, 1991). Therefore the resource-based perspective indicates that a more serious constraint to China's large state enterprises is the mismatch between the skills associated with bureaucratic coordination and those demanded by the market.

Section two reviews resource-based theories and their relevance to economic development in China. Section three describes how both internal reforms and external inducements have driven sector reforms. Section four argues that successful adaptation has been underpinned by the ability to learn from past experiences and apply this learning under market conditions by using inherited state networks and linkages. Section five outlines the limitations of the sectors critical resources in terms of developments in the international oil industry. Section six concludes.

\section{Critical resources, global pressures and the state}

Since the establishment of the Peoples Republic of China in 1949, the development of China's oil sector has been shaped by both internal and external influences. The sector benefited from Soviet expertise and technologies in the 1950s. Its loss led to the pioneering of innovative domestic techniques designed to overcome 
constrains (e.g. the Daqing Method) and emphasised self-reliance over foreign involvement, labour over scarce capital and political education over material incentives (Kambara \& Howe, 2007). Yet, despite these policies, the oil sector was never fully isolated from the global economy. During the late 1960s and 1970s rapid increases in production saw China become a net exporter of oil. As a result, the oil industry was well-familiar with the international oil industry. This exposure provided China's oil producers a readily available benchmark to compare domestic performance against. More recently as China moved from a net-exporter to netimporter of oil, the sector has undergone further rationalisation. On the one hand it separated producing assets from oil trading, keeping trading within the realm of central government and delegating production to enterprises. This insulated producing enterprises from the risks associated with oil trading. Secondly, within the producing assets, the industry was divided into upstream exploration mainly carried out by PetroChina and downstream refining mainly carried out by Sinopec. This type of reform allowed enterprises within the sector to benefit from state coordination, but it also lessened their autonomy in dealing with the market.

The experiences of China's oil sector suggest that theories of development based on institutional thresholds or privatisation and liberalisation are too narrow to explain the complexities of China's development model. On the other hand, the development of resource-based theories that focus on a firm's critical resources has facilitated the analysis of innovations that cannot be explained by market contracting alone. These include such firm-specific resources as organisational competencies, learning, knowledge, and organisational networks. Narrowly defined the resource dependency approach focuses on how board capital, which refers to the competencies and experiences of management, leads to the provision of resources to the firm (Hillman \& Dalziel, 2003). A broader definition views a firm's resources as linked to previous learning opportunities (Hoskisson \& Businitz, 2001). These may include among others, past business and learning experiences, industry expertise, managerial competencies, networks and connections. The possession of any of these resources will affect the cost/revenue structures of the firm, thereby giving it a resource position barrier, allowing the firm to earn economic rents (Wernerfelt, 1984, 1997). This is part of an emerging approach to the study of organisations that seeks to understand dynamism within constraints, by paying greater attention to the unique firm (Hagstrom \& Chandler, 1999). 
The resource-based approach is particularly relevant to understanding firmlevel innovations in China, where poorly defined property rights and high transaction costs often rule out the possibility of mitigating governance problems through such market-based solutions as privatisation. In this article, the resource perspective is applied to distinguish firm-specific features from the market/transaction cost approach. Instead of a nexus of contracts, the firm is viewed as a collection of specific investments built around a set of critical resources (Rajan \& Zingales, 1999). Underpinning this approach is how China, rather then transferring large public monopolies to the private sector, instead opted to change gradually the institutional rules and incentives for their management. The chosen reform path had an important economic logic. Despite the resource constraints of the pre-reform era, pragmatism, innovative capacity and indigenous techniques were common features of enterprise management (Rawski, 1975; Chen, 1978; Hsueh \& Liu, 1980). In the oil sector, considerable investment in research and pioneering indigenous techniques was undertaken, as is evident by the publications on refining in Chinese Scientific Journals during the 1950s (Williams, 1975, 244). Indeed a frequently overlooked feature of current enterprise management, many of whom started their careers in chaotic period between 1966 and 1976, is that they were already highly talented innovators.

Another feature of enterprise reform that needs to be accounted for within the resource-based framework is the role of the state. A distinguishing feature of China's approach was not so much how to revile state agencies and their bureaucrats, but rather how to reform them (Walder, 1995). Indeed Qian (2001) points out the comparative advantage of government over private control, where the institutional environment is weak and markets are at an early stage of development. The question remains however as to the extent the state can or should facilitate enterprises in the context of adapting to the global economy. Nolan (1998) argues that the normal path through which the world leading corporations developed was through state support. Economic history bears out this point. The granting of royal charters and limited liability was used extensively in $17^{\text {th }}$ and $18^{\text {th }}$ England to grant privileges to large international trading companies (e.g. Patterson \& Reiffen, 1990). Similarly the US adopted a trade-protection model to protect its emerging industries in the $19^{\text {th }}$ century.

The following sections examine how the internal critical resources of the petrochemical sector influenced the reform of the sector, and how these internal resources were induced and modified by external market incentives. The focus is on 
Sinopec and PetroChina, the two largest refiners in China, who together account for approximately $83 \%$ of China's crude oil. ${ }^{1}$ These enterprises are not just representative of the petrochemical sector, but also China's oil sector generally as they also account for a large proportion of on-shore exploration. Empirical data for this study come from two main sources. First, formal semi-structured interviews were conducted in Hong Kong and Beijing with enterprise directors, regulators and industry experts. The second source consists mainly of financial data, annual reports and media sources. It is worth noting that oil statistics can prove problematic generally, let alone in a developing economy. To overcome this problem, this paper relies on a combination of international sources and enterprise production statistics. The latter are mainly sourced from the 20-F report, which is independently audited and a requirement of listing in the United States.

\section{Internal restructurings and external inducements}

Despite the relatively early exposure to international prices, ideological constraints meant that the sector has remained firmly in state hands. ${ }^{2}$ This section outlines how early reforms in the sector formed part of the state's repeated attempts to streamline the bureaucracy and have recently evolved to address more complex issues such as welfare commitments, production constraints and market prices. Despite the large aggregate size of China's refining capacity, individual refineries remain small, and were overstaffed with workers who supplied their labour on the understanding that enterprises would look after their welfare. In addition the technology upon which the sector was founded, much of which originated from the former Soviet Union, was now dated. There also existed many geographically dispersed refineries in remote parts of the country, whose capacities were too small to be considered economically viable (Table 1). China’s growth has had two specific impacts on the oil sector. First, the upstream or exploration part of the sector has no longer been able to fully supply the downstream or refining part. Rising imports meant that the state could no longer afford to subsidise domestic oil consumption. Secondly, difficulties in increasing refining capacity have meant that domestic capacity can no longer match demand (see Figure $1 \&$ Table 1). These pressures led to an erosion of the privileged status of petrochemicals as purchasers of subsidised crude oil and a subsequent opening of the sector to international markets. 
(Table 1 and Figure 1 about here)

\subsection{Ministerial restructuring}

Prior to 1983, competing ministries controlled China's oil sector, resulting in an overlap of functions and an inefficient use of resources. Some large downstream refineries were under the administrative control of the Ministry of Textiles, while others were under the Ministry of Petroleum Industry. Weak control structures were worsened by geographical dispersion. China's principal source of domestic crude oil is located in North-eastern China. Many refineries are located in Eastern China while industrial demand tends to be concentrated in the coastal areas of the south and east. A limited transportation infrastructure made product distribution a costly and timeconsuming process. Two of the largest bottlenecks in the early 1980s were the energy and transportation sectors (Johnson, 1986). Increased demand for petroleum fuels in the early 1980s resulted in fuel shortages. Ministerial restructuring was therefore driven, not just by the desire to streamline the bureaucratic structure of the industry, but was also based on the desire to resolve economic bottlenecks.

In response to these problems the oil industry was separated into upstream (exploration) and downstream (refining) enterprises. China National Petrochemical Corporation, known as Sinopec was established in 1983 as a ministry level enterprise under the authority of the state council to regulate China's petrochemical refiners. Sinopec was organised along the lines of a large holding company. The new structure was intended to streamline the coordination of the smaller producing units or subsidiaries. Ministry level enterprises took responsibility for the operation and regulation of their respective enterprises, while the Ministry of Petroleum took care of administration. As part of this process the Ministry of Petroleum Industry handed over control of its major refineries to Sinopec. Responsibility for the upstream sector was given to China Petroleum Corporation, which in 1988 was replaced by China National Petroleum Corporation (PetroChina).

While streamlining the administrative structure eased coordination problems, it did not specifically address issues of efficiency or quality. Enterprises continued to operate as they had under the central plan. Once they complied with basic performance obligations, there was little obligation to achieve cost reductions or efficiency improvements. Moreover, during the 1960s and 1970s the emphasis was on maximising production. Considerable effort was invested in increasing crude oil 
production. Improving production at Daqing necessitated the installation of hundreds of submersible pumps (Woodard, 1986). These efforts resulted in significant increases in production (Figure 1), but did not necessarily lead to improvements in efficiency or quality. Woodard (1986) notes maintaining production life at Daqing required increasing quantities of water. Crude oil from Shengli Oilfield, the second largest production complex, had serious sand control problems and a high residual content. This posed particular difficulties for refineries, limiting the range of products that could be produced and making the refining process more costly.

\subsection{Overcoming internal production constraints}

In the past a combination of infrastructural bottlenecks and state protection meant that China's domestic petrochemical producers faced limited competition. China's large refineries are all under the control of either Sinopec or PetroChina, concentrated in the north of the country and tend to be small by international standards (Table 1). Transportation difficulties and a limited infrastructure resulted in competition on a regional basis. Foreign exchange restrictions for the purchase of imports helped protect domestic producers. Petrochemical companies also benefited from crackdowns on smuggling and controls on cheap imports.

The product market for petrochemicals in China has experienced considerable change. The growth in industries like garments and textiles, plastics, and agriculture, are dependent on the supply of petrochemical products (Nolan, 2001). To satisfy domestic demand, China has become a net importer of petrochemical products. Since 1993, most petrochemical products have been sold at market prices. This was a necessary response to increasing oil imports at international market prices. Enterprises needed greater pricing flexibility in order to reflect more expensive inputs. Restrictions on the purchase of foreign exchange were also relaxed, allowing importing enterprises to purchase foreign currency from PRC banks once they produced the relevant sales contract. This made it much easier for manufacturers to import petrochemicals, creating a more competitive market for domestic producers.

China's quest to become a signatory to the General Agreement on Trade and Tariffs (GATT) and a member of the WTO illustrated a clear recognition at the political level of the need to encourage petrochemical imports. In April 1996 China reduced its general level of tariffs on imports from $36 \%$ to $23 \%$. For petrochemical companies, this had the effect of reducing the tariffs on imported products in their 
product markets from a range of $9 \%$ to $40 \%$, to a range of $5 \%$ to $22 \%$. ${ }^{3}$ The implementation dates were also comparatively soon with tariffs on imported ethylene, synthetic resins and fibres, and gasoline scheduled to fall significantly after 2003, 2008, 2004, and 2001 respectively.

\subsection{International listings}

Even before China's large petrochemicals listed on international stock markets, most large international companies already had some sort of business dealings in China. The purpose of listing was therefore to increase the knowledge of international practices, expose management to the international investment community and further facilitate streamlining with the sector.

"International listing represented a progression of political efforts to promote the efficiency of SOEs. The government wanted SOEs to engage in international capital markets as it gave them more exposure to international business practices” 4

Prior to this, production units were simply obliged to report production indices and profits to the state. International listing meant that profits had to be reported to shareholders. It also came with a commitment to reduce costs and become more transparent. ${ }^{5}$ More significantly, listing introduced changes to the governance of enterprises. From a managerial perspective this results in changes in decision-making and corporate strategies, as shareholders required profits and production indices to be related to a sustainable cost reduction strategy. ${ }^{6}$

The strategic importance of the oil sector and the need to integrate international standards was reflected in the listing of Shanghai Petrochemical Company (SPC), a subsidiary of Sinopec, in June 1993. As one of the first petrochemical complex built entirely from international technology, it became one of the first nine Chinese state enterprises to be listed on both domestic and Hong Kong markets under the 1993 Company Law. It was stressed in the listing prospectus that although the state would have a controlling interest in SPC and some of its primary competitors through Sinopec, management of the company would be entirely the responsibility of SPC's board of directors. ${ }^{7}$ Despite these reassurances, it is interesting to observe that it was concerns over the financial health of Sinopec that led to the withdrawal of two of SPC's underwriters prior to the IPO. ${ }^{8}$ Yet, despite these 
problems, other large refineries such as Jilin Chemical Company, a subsidiary of PetroChina, were listed on the Hong Kong market during the 1990s.

The international floatation of Sinopec and PetroChina in 2000 signalled further standardisation of the bureaucratic structure of the industry. In advance of listing both received injections of producing assets from their respective ministry level parent groups. After the flotation, China Petrochemical Corporation controlled $55.06 \%$ of Sinopec, which in turn controlled 57 percent of SPC. Other significant Sinopec shareholders include China Development Bank (10.12\%) and China Cinda Asset Management (10.06\%) bringing the total state shareholding to just over $77 \%$ of the stock. This gave Sinopec a more diverse shareholder base and further standardised its relationship with the state. However, just as Sinopec retained control over managerial appointments at SPC, the state retained control (through Sinopec Group) over appointments at Sinopec. After PetroChina's IPO on the Hong Kong and New York stock markets, the state retained a 90\% controlling share through CNPC. Similar to Sinopec's controlling share in SPC, PetroChina held a 67 percent share in the Hong Kong listed Jilin Chemical Company.

As a consequence, the new governance structure remained very similar to the hierarchical and bureaucratic structure that had preceded it. Sinopec and PetroChina were created at the macro level to solve the problem of coordinating the smaller micro-level refining and production units such as SPC and Jilin Chemical. However the number of layers in the hierarchy threatened to undermine the original intentions. The growth of enterprise level production units like SPC and Jilin threatened to weaken the degree of central co-ordination of the newly emerging large enterprises (Nolan, 2001). The structure gave the state strategic control over enterprise assets, but created considerable uncertainty over how these assets should be used. Under such uncertainty, there is very limited accountability to minority shareholders, and corporate governance concerns effectively go out the window. This has prompted further rationalisation as large enterprises such as PetroChina and Sinopec absorb smaller listed production units. ${ }^{9}$

\subsection{Financial rationalisation and rewarding employees}

For industrial enterprises dismantling the "iron rice bowl” was a central aspect of enterprise reform. The vast welfare commitments inherited from central planning were difficult to reconcile with commitments to international capital markets. This 
transition involved two stages. The first was to shed excess labour. This process was to some extent facilitated by the listed companies' parent companies who inherited the enterprises social functions. The second involved rewarding remaining employees with a market rate of pay based more closely on productivity.

Prior to floatation, Sinopec employed 508,168 workers while PetroChina employed 480,012 workers in 1999. Employee costs stood at 5.5\% and 8.7\% of total costs respectively (Table 2). Both enterprises had to shoulder significant employee severance costs in the aftermath of listing, In terms of severance, Sinopec offered workers a package based on the number of years of service. ${ }^{10}$ In preparation for Sinopec's IPO, Sinopec Group injected producing assets but retained services and utilities including hospitals and schools. In this manner the parent company took care of much of the original group's welfare commitments.

The effect of these policies on Sinopec and PetroChina was that by 2006, the number of workers had been reduced to 340,886 and 446,290 respectively. Employee costs represented $2 \%$ and $8 \%$ of total costs respectively. While this represented an important reform, a more significant feature in terms of China's overall economic reforms was how the reduction in employees was accompanied by a better system of rewards for those who remained. Figure 2 shows how the average real wage of both enterprises has increased significantly since 2000. A more sceptical interpretation of these trends would suggest that employee wage trends have merely reflected wage improvements in the state sector generally, or that improvements represent compensation for a loss in welfare benefits.

It is however worth noting that although reductions in SOE employment generally occurred as early as 1996, Sinopec and PetroChina did not undertake significant reductions their workforces until 2000. Prior to this, there appears to have been less urgency to reduce its workforce. Viewed from another perspective, as part of ministry level enterprises, management enjoyed less flexibility on these issues. International listing allowed greater latitude in reducing employees. Petrochemical companies have also started to differentiate salaries based on the type of work. Previously under central planning there was no monetary difference between positions. In 2003, Sinopec raised salaries for certain workers based on a study of the market rate for each type of work and applied this accordingly. ${ }^{11}$ The pay structures of senior level directors have also changed. Directors remuneration now consists of $30 \%$ fixed pay and $70 \%$ variable or performance related pay. Although remuneration remains 
low by international standards, these developments represent an important departure from past management strategies.

\section{(Table 2 and Figures 2 \& 3 about here)}

\section{Learning from the market}

The market structure of the petrochemical sector is not unlike that which emerged in other state sectors such as telecoms. Two state enterprises, Sinopec and Petrochina, emerged as the products of ministerial reorganisation and restructuring. Yet, the outcome has been very different from the state telecom sector (Tobin and Sun, 2007). This section describes how despite their relative inexperience with markets, enterprises in the petrochemical sector adopted a more measured approach to competition. Enterprises were relatively quick at adapting to international prices and competing under market conditions. Significant factors that facilitated this include a realistic approach to price regulation, an early exposure to market prices, credible regulation and inherited organisational networks. What is significant is that these factors include a combination of internal critical resources and external inducements. The ability of these state enterprises to deal with the legacies of central planning suggests that contrary to the orthodox approach to transition, bureaucrats do possess a range of critical resources that can be applied under market conditions.

\subsection{Early price reform}

Although management in the petrochemical sector would have had little prior experience of competitive market prices, their exposure to the price mechanism occurred comparatively sooner than that of other sectors. Since the 1990s, the state has had to encourage imports in order to ease supply problems. Petrochemical enterprises had to purchase an increasing portion of crude oil at international market prices. Subsidised prices became unsustainable and prices for both inputs and products were priced more closely to the market rate.

For Sinopec the effects of liberalisation were particularly clear. Increased demand and the failure to develop new production saw the quantity of crude oil that it could supply itself decline from $34.7 \%$ to $20.4 \%$ (Table 2). This has affected Sinopec's cost base, with crude oil increasing from $69.8 \%$ of total costs to $86.8 \%$. Figure 3 illustrates how Sinopec's average cost per barrel of crude oil is now largely 
determined by the international crude oil price. Data from Sinopec's subsidiary SPC suggests that the convergence with international prices may have occurred as early as 1997. This has affected production costs (Figure 3). When SPC listed in 1993, it paid an average price of $651 \mathrm{RMB}$ per ton of crude oil compared to a market price of 1,040 RMB per ton. Throughout the 1990s the discount between the international and domestic price continually declined. By 2000, SPC paid an average of 1,802 RMB per ton, compared to and international price of 1,856 RMB per ton.

PetroChina's inheritance of significant upstream production assets insulates it from international prices to a much greater extent than Sinopec. PetroChina has benefited from market prices as its selling price has increasingly reflected the price of international crude (Figure 3). As a result it has much higher returns on sales than Sinopec. While this illustrates the importance of inherited state resources, it is also worth noting that greater exposure to international prices has induced a much greater level of reform at Sinopec. Compared to PetroChina, Sinopec achieved greater reductions in relative costs, reductions in employees and increases in profit per employee. Moreover the failure to discover new supplies and rising domestic demand has seen PetroChina’s rate of self-supply decline from 97.7\% to 82\% (Table1).

\subsection{Credible regulation}

Exposure to market prices necessitated regulatory reforms. Even before market reforms, there already existed a complex system of price regulation. As such management already had some familiarity with regulatory pricing. In addition political considerations and the closeness of ministry-level enterprises to regulatory process aided the establishment of a credible regulatory system. For example the chairman of listed companies such as PetroChina, would also be chairman of the ministry level parent company. The expertise and political influences of oil enterprises has resulted in their closeness to the energy policy process (Downs, 2004).

Prior to 1993, petrochemical enterprises faced a three tier pricing system for crude oil. This consisted of a price heavily subsidised by the state (a state low price), a less heavily subsidised price (a state high price), and an unsubsidised market price. For example, in 1992 the state low price for crude oil from Daqing and Shengli was RMB265 per ton; the state high price for oil from Daqing and Shengli was RMB621 and RMB544 respectively; and the market price was RMB 1,000 per ton. In 1993 the 
pricing system was reformed and all subsidised oil was charged at the state high price. This coincided with China's first year as a net importer of oil.

Benchmarking the price of oil and gas to international prices became an economic necessity once China became a net importer. For enterprises like Sinopec, it was important in order to maintain competitiveness, that the government's prices of crude and oil products were more closely related to the international price. Up until 2001, the prices of petrochemical products were generally updated monthly on the basis of Singapore prices. For example, between November 1999 and August 2000, the state raised oil price on six occasions in an attempt to keep pace with international developments and protect enterprises from volatile oil price movements. ${ }^{12}$ However such adjustments encouraged the hoarding of inventories as enterprises could easily predict future price movements. ${ }^{13}$ The decision in October 2001, to switch to the issuing of guidance prices based on prices in three international markets therefore represented an important shift in regulatory policy. Although the state still retained some control over prices, the new pricing structure was significantly flexible enough to allow enterprises price products according to input costs.

Guidance prices are calculated on a transparent formula thereby allowing enterprises more certainty. While the prices of chemical products tends to be weakly regulated, allowing enterprises to compete more freely with cheap imports, the price of gasoline and diesel tend to be moderately regulated, as crude oil is traded at the international price. However, on occasion the government has not increased the price in line with international market trends. After the SARS crisis, the government was reluctant to raise prices because it was felt that some industries would be adversely affected. The influence of such political considerations on regulatory prices has the potential to create regulatory risk for China’s refiners.

\subsection{Learning to compete}

A credible system of regulation is not enough in itself, as enterprises must also know how to compete in a value maximising manner. Initially petrochemical firms, freed from the type of central control they had been accustomed, took advantage of the liberalised market structure and engaged in a price war. Both Sinopec and Petrochina slashed petrol prices in attempt to dominate the market in central and Eastern China. ${ }^{14}$ The price war was reportedly sparked by the reduction in the factory price of petrol by the State Planning Commission in repose to international price 
changes. However, there was evidence to suggest that competition was already taking place before the price change. Petrol stations in Shanghai were reported as saying that rivalry began some time before and was most intense in eastern Zhejiang Province and south-western Sichuan Province. ${ }^{15}$ As newly listed enterprises with international shareholders, both companies were under pressure to strengthen their domestic positions ahead of WTO accession.

What is worth noting is that rivalry did not develop into an all out price war, despite the fact that both producers had ample scope to continue to reduce prices. The reform of the pricing system, announced in October 2001, gave producers greater flexibility allowing them to set prices eight percent, instead of five percent, up or down of the guidance price. More significantly enterprises also agreed to engage in coordinated stabilisation efforts. These included setting refining throughput in accordance with market demand, better balancing of crude oil resources between enterprises in order to reduce reliance on imports, and managing PetroChina's sales of refined products in Sinopec's territory in order to avoid product dumping. This type of coordination signalled a clear understanding of the market mechanism. It is also possible that political considerations played an important role in preventing excessive competition. Both enterprises emerged from the restructuring of China Petrochemical Corporation. An official at CNPC, noted even before the state intervened, they would "from now on [...] stage an all out friendly competition" against Sinopec. ${ }^{16}$

\subsection{Organisational linkages}

It is clear that the organisational linkages inherited from the system of central planning have provided a method for smoothing the transition process. As noted already, the close linkages between enterprises and their ministry level parents has been crucial in implementing a credible system of regulation and coordinating competition as well as dealing with the social functions of enterprises. Close linkage have also offered a means of realising and rewarding the vast experiences of enterprise management. Both Sinopec and PetroChina are directed by former bureaucrats, most of whom began working in China's oil sector in the 1960s or early 1970s. During this period China achieved major developments in terms of exploration

and refining. ${ }^{17}$ These directors have vast experience of China's political and economic institutions in addition to technical knowledge of the oil industry. 
Although the corporate governance literature has highlighted significant benefits to using international independent directors (e.g. Sun \& Tobin, 2005), both Sinopec and PetroChina have shown a preference for domestic directors. This is partly due to the strategic nature of the sector, but also their ability to draw on directors with past experiences. Sinopec utilised the experiences of directors at SPC in preparation for its international flotation. These directors started their careers as petrochemical engineers, were rewarded for their vast experience and knowledge of China's petrochemical industry, through promotion within the Sinopec Group. In this way, the process offered former bureaucrats the incentives to apply previous competencies under market conditions.

Organisational linkages are also evident in the cooperation between parent companies and their listed subsidiaries. Sinopec used it relationship with the Sinopec group to gradually acquire its producing assets and help hive off those considered to be non-performing. This allowed Sinopec a much freer hand in converging with market economy principles. Similarly, both Sinopec and PetroChina rely on their parent companies, to conduct such overseas business as securing access to suppliers of crude oil. Undertaking such work themselves, would be too risky. One of the main aims of the listed company is to reduce the level of risk it faces. In this way, organisational linkages, rather than representing an obstacle to reform they have enabled enterprises to adapt to the challenges posed by economic transition.

\section{International convergence and it limits}

Among the notable reforms in the oil industry was the early commitment by the state that the sector should reflect international developments as much as possible. The early exposure to international trends and benchmarks appears to have paid off, in the form of enterprise adaptation and price liberalisation. However, the strategic position of the industry means that there is always the possibility of arbitrary political or regulatory intervention. Similarly, although management in the industry now benchmark themselves against international oil majors, enterprises ultimately lack both the scale and autonomy to compete on an international basis. In a sense the challenges facing the sectors future integration have shifted from dealing with the legacies of central planning such as inefficiencies, capital constraints and excess labour, towards those concerning how to resolve capacity constraints and global 
energy supply issues. Resolving these issues requires a degree of management skill far more complex than is required for resolving production issues.

\subsection{Production and managerial constraints}

At a corporate level, both Sinopec and PetroChina now view themselves as comparable to other international oil firms. Indeed the aim of state policy is to portray these enterprises as internationally competitive players (Nolan, 2001). However, the production capacities of both companies suggest that they remain on a smaller scale than the international oil majors. Fig. 1 illustrated how China's oil consumption has grown rapidly, but that in recent years supply and capacity have failed to keep pace. This suggests that even if supply problems were solved, China would also face a capacity constraint. In the first instance China's infrastructure is not equipped to deal with large scale oil refining (Kambara \& Howe, 2007). Secondly, at enterprise level individual refineries are constrained by their size. The international capacity standard is of the order of 10 million tons of crude per year or approximately 71 million barrels per year. Table 1 shows how, at the time of listing in 2000, only three of China's major refineries met this standard. By 2006 this number had risen to eight. Although this is an impressive improvement, it also illustrates that the capacity levels of most of China's major refineries are below the international capacity standard. More worrying is that almost half of the total refining capacity falls into the category of below 35 million barrels per year; the implication being that these refineries would simply not economically viable and only survive because they are part of a large group.

The distribution of capacity within the industry is also replicated in the organisational structure. Although the organisational structure of both Sinopec and PetroChina is not unlike that of oil majors such as BP or Shell, they lack the unified structure of these companies (Zhang, 2004). While the decision to allow such smaller subsidiaries as SPC and Jilin to gain some autonomy proved beneficial from a learning perspective, their parent companies now face the challenge of reintegrating them into the group structure (Nolan, 2001; Zhang, 2004). Both Sinopec and PetroChina have recently been focusing on reducing the overlapping of activities and streamlining management structures by consolidating smaller listed companies into the larger integrated company. In 2006, Sinopec outlined plans to privatise four of its domestic listed subsidiaries. ${ }^{18}$ While these plans will help further streamline management within the sector, they are unlikely to deliver capacity improvements. 
Capacity constraints ultimately point to managerial constraints within the sector. In terms of technical management, the history of domestic innovation both within the sector would suggest that both Sinopec and PetroChina are arguably comparable to international companies. However it is clear that management are still learning how to compete in a global market. This learning is constrained by ideological barriers to hiring foreign directors. While both enterprises have invested significant effort into complying with the regulations of international stock exchanges, a more difficult challenge for enterprises is managing in the international environment. With major refineries operating at rates of over $90 \%$ capacity utilisation, there is limited scope to increase production internally. The challenge is now to build extra capacity. This is not so easy to achieve. Refining has become more technical, as refiners not only have to deal with low quality domestic inputs, but are also expected to produce to a higher standard, in order to compete with international products. As early as the 1970s, China imported refining equipment and technology from $\mathrm{ABB}$, an international company specialising in ethylene purification technology. $\mathrm{ABB}$, along with Exxon Mobil, BP and Shell later agreed to invest in Sinopec's IPO. ${ }^{19}$ The main difference between refining and exploration equipment is that given it more complex nature, refining technology tends to be proprietary and more difficult to develop. Sinopec noted that for technology on the chemical side it was necessary to engage in joint ventures with ABB, BP, Shell, and Exxon Mobil. ${ }^{20}$ The crucial nature of these joint ventures is illustrated by the willingness of Sinopec to grant concessions to strategic investors. It negotiated a deal with Exxon Mobil allowing it access to a joint venture in gasoline stations. ${ }^{21}$ Exxon possessed important proprietary hydrocarbon technologies. In 2002, Sinopec signed an agreement to strengthen its cooperation with Exxon Mobil involving the construction of a joint-owned refining and petrochemical complex in Fujian province. ${ }^{22}$

\subsection{Political constraints and past legacies}

Although the petrochemical sector has benefited from its close connections to the state, its status as a strategic industry has also hindered its further development. For example, enterprises have used their parent companies to engage in oil trading and to find international partners for the construction of large refineries. This has had the effect of lessening the risk to the listed company, allowing it to focus on the operational side of its core businesses. However it has also lessened the autonomy of 
enterprises and created greater regulatory and political risk. Rising international energy prices, issues of energy security and oil nationalism have resulted in a strong political dimension to international oil deals.

The problems of scale in the sector have meant that enterprises have had to rely to a large extent on the state-owned parent companies to expand capacity. As China's largest refiner, Sinopec has increased its refining capacity from 720 million barrels per year in 2000 to 1,250 million barrels in 2006. Yet, the magnitude of this improvement has much to do with greater utilisation of existing capacity, while increases in capacity have been largely determined by purchasing extra capacity from its parent company. Shortly after listing, Sinopec purchased Sinopec National Star from its parent, with the expectation that deal would boost Sinopec's crude oil capacity by $10 \%$ in the near term, and up to $30 \%$ in the long term. ${ }^{23}$ PetroChina, whose parent company CNPC inherited mainly producing upstream assets, although possessing roughly similar refining capacity before listing has not achieved the same level of capacity improvements as Sinopec, but has benefited from the transfer of upstream assets.

While close connections to the state have in many ways helped create a stable regulatory environment, they have also created regulatory risk. For example, in 2006 the state imposed a special oil income levy on the sale of locally produced oil. ${ }^{24}$ In 2003, the government delayed adjusting prices, as it was feared that higher fuel prices might hurt some of the country's more vulnerable industries. ${ }^{25}$ Although politically popular, such interventions create regulatory risk for enterprises and international investments. Fuel prices are generally a politically contentious issue. In late 2007, as the price of crude oil rose above $\$ 90$ a barrel, the state was forced to raise domestic fuel prices by $10 \%$ in order to keep refineries viable. To cushion the public against these increases, the Beijing local government increased the monthly subsidy to taxi drivers to 780 Yuan to help defray rising fuel costs and keep fares low. ${ }^{26}$

Similarly, while the separation of oil trading from production and refining has lessened the risk to enterprises, the policy has yet to deliver a fully secure source of oil for refiners. Moreover it has exposed enterprises to international political and business risks. China accounts for approximately 6.8\% of world exports (BP, 2006). While China's oil traders are regarded as highly experienced and possess a sophisticated understanding of world markets, most international oil trades take the form of direct deals between companies and major exporters thereby limiting the 
quality of available freely traded oil (Kamabra \& Howe, 2007). Although China accounts for a relatively small proportion of world demand, much smaller than US, Europe or Japan, it's oil is relatively expensive (see Figure 3) so any reduction in supply or a continued rise in price are likely to adversely affect domestic refiners. The implication is that it needs to diversify. However this is not easily achieved. Recent attempts to purchase the producing oil assets of US oil firm Unocal Corp. by China National Offshore Oil Corp. (CNOOC) illustrate the difficulties involved in this strategy. Rival bidders such as Chevron hired lobbyists to sway the opinion of the general public and political leaders by focusing on the Chinese state's involvement (see Hufbauer et al, 2006). Eventually Chevron's offer succeeded despite the fact that it had offered US\$700 million less than CNOOC. More recent attempts at diversification have focused on the African continent, which in total now represents China's second leading source of oil, accounting for over $20 \%$ of oil imports (Table 3). This too has created problems. PetroChina's involvement in Sudan led to severe criticism by international investors. This has introduced an element of external political risk in investments, a feature which China's enterprises had previously been insulated from.

(Table 3 about here)

\section{Conclusions}

The petrochemical sector illustrates how organisational cultures and resources inherited from the pre-reform era, if provided with the correct incentive structures, can survive economic transition and be successfully applied under market conditions. The study indicates that numerous critical resources were mobilised in the development of the sector. These included the complex history of the sector, its management and the commitment of the state to expose the sector to international developments where possible. Early experiences with the international oil market, price controls and state production indices meant that management were much more familiar with the concept of credible market regulation. These experiences in addition to the supervisory role of the state arguably aided the coordination of competition within the sector, even though the regulatory structure falls far short of international regulatory standards. Exposure to international market prices also meant that enterprises in the petrochemical sector were subject to international benchmarks at an 
earlier stage of the reform process. The oversight of international capital markets ultimately lessened the need for full privatisation. The diffusion of market-based learning throughout the organisational networks inherited from central planning lessened the urgency to introduce international management. The consolidated structure of enterprises has also been used to engage in international joint ventures, achieve greater organisational efficiencies, and reward innovative and experienced management.

From a theoretical perspective this type of resource-led development is significant as it provides another lens on China's development. Although many critical resources were inherited from the system of central planning and are typically viewed as problematic in terms of their property rights configuration, they can also be used to promote effective organisational learning and adaptation. At enterprise level, dealing with high transaction costs is in itself a learning experience. The question remains however as to whether management can learn fast enough. Exposure to international market prices and practices has also highlighted ambiguities within the sector. Critics argue that state-led reforms in the oil sector are ultimately chasing a fast moving target (Zhang, 2004). Competing in an international market with high prices, scarce resources and complex political motive places additional demands on management. While political resources have undoubtedly smoothed the transition process, they have also hindered international progress. This was succinctly illustrated in the cases of CNOOC in the US and PetroChina in Sudan. Similarly, domestic management and technologies have served the industry well, but Kambara \& Howe (2007) question the potential of indigenous technologies to expand output over the long run. Ultimately the past development of the sector indicates that resources matter, but what may matter more is to continue to improve the incentive structures for their application. 


\section{Notes}

\footnotetext{
${ }^{1}$ This estimate is based on 2005 refinery aggregate capacities of PertoChina and Sinopec over China's total refinery capacity as provided by BP (2006).

${ }^{2}$ For a review of the factors that differentiate the energy sector from other industries and how they result in a cautious approach to energy privatisation, see Andrews-Speed and Cao (2005). Williams
} (1975) suggests that the CCP's ideological aversion to foreign involvement stemmed from the pre-1949 exploitation of China's oil resources by Japan and international oil companies from the US and UK.

${ }^{3}$ Sinopec Shanghai Petrochemical Company Annual Report (1996, 21).

${ }^{4}$ Interview: Sinopec Head Quarters, Beijing 12 ${ }^{\text {th }}$ August 2004.

${ }^{5}$ Sinopec committed itself not just to complying with US accounting standards but also to reducing costs by US $\$ 1.6$ billion and integrating modern technology. "Investors to China: Open those Books" Businessweek Online $23^{\text {rd }}$ October 2000.

${ }^{6}$ Interview: Sinopec Head Quarters, Beijing $12^{\text {th }}$ August 2004.

${ }^{7}$ See SPC International Listing Prospectus, 23 ${ }^{\text {rd }}$ July 1993.

${ }^{8}$ Standard Chartered Securities and Wardley Corporate Finance (the merchant banking arm of HSBC) withdrew from SPC's public offering. "The Reds are Coming" Global Custodian, September 1993.

${ }^{9}$ For example in May 2007 Jilin Chemical entered a Merger by Absorption Agreement, which effectively saw PetroChina purchase the outstanding shares of Jilin and absorbing them into the larger PetroChina group. See: http://www.jcic.com.cn/PROMPTER\%20ANNOUNCEMENT\%20IN\%20RESPECT\%20OF.doc

${ }^{10}$ According to Sinopec, many workers took this offer and started their own businesses. Interview: Sinopec Head Quarters, Beijing 12 ${ }^{\text {th }}$ August 2004.

${ }^{11}$ Interview: Sinopec Head Quarters, Beijing $12^{\text {th }}$ August 2004.

12 "Petrochemical industry reels from oil price rise" Peoples Daily, $28^{\text {th }}$ August 2000.

${ }^{13}$ Hong Kong Trade Development Council: Business Intelligence China-No.8, December 2001.

${ }^{14}$ In July 2001, a litre of petrol cost 2.58 Yuan. In August Sinopec was charging 2.41 Yuan/litre and PetroChina 2.36 Yuan/litre. South China Morning Post, 14 ${ }^{\text {th }}$ August 2001.

15 “Giants face off in petrol skirmish” South China Morning Post, 14 ${ }^{\text {th }}$ August 2001.

16 “Giants face off in petrol skirmish” South China Morning Post, 14 ${ }^{\text {th }}$ August 2001.

${ }^{17}$ For example, between 1959 and 1974, China increased its crude oil production from 3.7 million tons to 65.3 millions tons. In 1960, China's refining technology was roughly equivalent to that of the US in the 1930s. By the mid 1970s, refining technology was roughly equivalent to that of any Western country in the late 1950s. Source: Williams (1975).

${ }^{18}$ Sinopec to Privatise Four A-share listed Subsidiaries” Sinopec Announcement $16^{\text {th }}$ February 2006.

${ }^{19}$ ABB Press Release (Zurich), $12^{\text {th }}$ September 2000.

${ }^{20}$ Interview: Sinopec Head Quarters, Beijing $12^{\text {th }}$ August 2004.

21 “Exxon adds 500-outlet to deal to Sinopec stake," FT, 12 $2^{\text {th }}$ September 2000.

${ }^{22}$ The agreement involved the investment of US\$3 billion to expand capacity from 80,000 to 240,000 barrels per day and building of a new ethylene steam cracker. "Sinopec firms up alliance with Exxon" CNN (Hong Kong) 22 ${ }^{\text {nd }}$ October 2002. 
23 “Sinopec buys unit from parent” FT, 12 ${ }^{\text {th }}$ June 2001.

${ }^{24}$ The levy applies to the sale of locally produced oil that exceeds US\$40 a barrel. Sinopec Announcement to the Hong Kong Stock Exchange, $3^{\text {rd }}$ April 2006.

${ }^{25}$ Interview: Sinopec Head Quarters, Beijing $12^{\text {th }}$ August 2004.

26 "Beijing increases subsidy to taxi drivers following fuel price hike" Peoples Daily, $11^{\text {th }}$ November 2007. 


\section{References:}

Andrews-Speed, P., \& Cao, Z, (2005) Prospects for Privatisation in China’s Energy Sector” in Green, S. \& Liu, G.S. (eds.), Exit the Dragon: Privatisation and State Control in China (Oxford: Blackwell), pp. 196-213.

B.P. (2006) BP Statistical Review of World Energy, June 2006.

Business Week Online http://www.businessweek.com/

Chandler, A.D. (1977) The Visible Hand: The Managerial Revolution in American Business (Cambridge: Harvard University Press).

Chen, N.R. (1978) Economic Modernisation in Post-Mao China: Policies, Problems and Prospects in Chinese Economy Post-Mao, Volume 1, Policy and Performance, A Compendium of Papers submitted to the Joint Economic Committee Congress of the United States (US Government Printing Office Washington), pp. 165-203.

Downs, E.S. (2004) The Chinese Energy Security Debate, The China Quarterly, No. 177, pp. 21-41.

Financial Times (FT) www.ft.com

Hagstrom, P., \& Chandler A.D. (1999) Perspectives of Firm Dynamics, in Chandler, A.D., Hagstrom, P. \& Solvell, O. (eds), The Dynamic Firm: The Role of Technology, Strategy, Organisation, and Regions (Oxford: Oxford University Press), pp. 1-12.

Hillman, A.J. \& Dalziel, T. (2003) Boards of Directors and Firm Performance: Integrating Agency and Resource Dependence Perspectives, Academy of Management Review, Vol. 28 (3), pp. 383-396.

Hong Kong Trade Development Council (2001) Update on China's Petroleum and Petrochemical Industry, Business Intelligence China No. 8, December 2001.

Hoskisson, R. \& Busenitz, L. (2001) Market Uncertainty and Learning Distance in Corporate Entrepreneurship Entry Mode Choice, in Hitt M., Ireland, R., Camp, S. \& Sexton, D. (eds.), Strategic Entrepreneurship: Creating a New Integrated Mindset (Oxford: Blackwell Publishers).

Hsu, R.C. (1991) Economic Theories in China, 1979-1988 (New York: Cambridge University Press).

Hsueh, T. \& Liu, P. (1980) Factors accounting for China's early Success in Industrialisation 1949-76, in Jones J.F. (ed.) Building China: Studies in Integrated Development (Hong Kong: Chinese University Press), pp. 27-50. 
Hufbauer, G.C., Wong, Y. \& Sheth, K. (2006) US-China Trade Disputes: Rising Tide, Rising Stakes, (Washington DC: Institute for International Economics).

Johnson, T. (1986) The Structure of China's Petroleum Industry, in Fesharaki, F. \& Fridley, D. (eds.), China's Petroleum Industry in the International Context (London: Westview Press) pp. 1-13.

Kambara, T. \& Howe, C. (2007) China and the Global Energy Crisis (Cheltenham: Edward Elgar).

Kose, M, Prasad, E. Rogoff, K., \& Wei, S. (2007) Financial Globalization beyond the Blame Game, Finance and Development, Vol. 44 (1), pp. 9-13.

La Porta, R., Lopez-De Silanes, F., Shleifer, A. \& Vishny, R. (2000) Investor Protection and Corporate Governance, Journal of Financial Economics, Vol. 58 (1), pp. 3-27.

Lazonick, W. (1991) Business Organization and the Myth of the Market Economy (Cambridge: Cambridge University Press).

Nolan, P. (1998) Indigenous Large Firms in China's Economic Reform: The Case of Shougang Iron and Steel Corporation, Research Notes and Studies No. 12, Contemporary China Institute, SOAS.

Nolan, P. (2001) China and the Global Business Revolution (Palgrave: Basingstoke).

Patterson, M. \& Reiffen, D. (1990) The Effect of the Bubble Act on the Market for Joint Stock Shares, The Journal of Economic History, Vol. 50 (1), pp. 163-171.

Peoples Daily (English Version) http://english.peopledaily.com.cn/

PetroChina, Annual Reports and 20-F Filing.

Qian, Y. (2001) Government Control in Corporate Governance as a Transitional Institution: Lessons from China, in Stiglitz, J., \& Yusuf, S. (eds.), Rethinking the East Asia Miracle (Oxford: Oxford University Press), pp. 295-322.

Rajan, R. \& Zingales, L., (1999) The firm as a dedicated hierarchy: A theory of the origins and growth of firms, Working Paper, The University of Chicago, Graduate School of Business: http://gsblgz.uchicago.edu.

Rawski, T. (1975) Problems of Technology Absorption in Chinese Industry, The American Economic Review, Vol. 65(2), pp. 383-388.

Schumpeter, J. (1928) The Instability of Capitalism, The Economic Journal, Vol. 38 (151), pp. 361-386.

Singh, A. (1995) Corporate Financial Patterns in Industrialising Countries, Washington DC, World Bank. 
Sinopec Corporation, Various Annual Reports and 20-F Filing.

Shanghai Petrochemical Company: Annual Reports and IPO Prospectus (1993)

South China Morning Post (SCMP) www.scmp.com

Sun, L. \& Tobin, D. (2005) International Listing as a Mechanism of Commitment to More Credible Corporate Governance Practices: the case of the Bank of China (Hong Kong), Corporate Governance: An International Review, 13(1) pp. 81-91.

Tobin D. \& Sun, L. (2007) Inducement Mechanisms for Entrepreneurship in the State Sector: China's Telecommunication Industry as an Illustrative Case, CeFiMS Discussion Paper 69 http://www.cefims.ac.uk/cgi-bin/research.cgi?id=62

Wernerfelt, B. (1984) A Resource-Based View of the Firm, Strategic Management Journal, Vol. 42, pp. 7-25.

Wernerfelt, B. (1997) A Resource-Based View of the Firm, in Foss, N.J. (Ed.), Resources, Firms, and Strategies: A Reader in the Resource Based Perspective, (Oxford: Oxford University Press), pp. 117-130.

Williams, B. (1975) The Chinese Petroleum Industry: Growth and Prospects” in China: A Reassessment of the Economy, A Compendium of Paper submitted to the Joint Economic Committee of the United States, $10^{\text {th }}$ July 1975, (Washington: U.S. Government Printing Office), pp. 225-263.

Woodard, K. (1986). Development of China's Petroleum Industry: An Overview” in Fesharaki, F. \& Fridley, D. (eds), China's Petroleum Industry in the International Context (London: Westview Press), pp. 93-126.

Zhang, J. (2004) Catch-Up and Competitiveness in China: The Case of Large Firms in the Oil Industry (London: RoutledgeCurzon). 
Table 1: Production capacities of China's major petrochemical refineries (Unit: Million barrels / year)

\begin{tabular}{|c|c|c|c|c|c|c|c|}
\hline & 1998 & 1999 & 2000 & 2004 & 2005 & 2006 & $\begin{array}{l}\text { Capacity } \\
\text { Utilisation } \\
2006(\%) \\
\end{array}$ \\
\hline \multicolumn{8}{|l|}{ PetroChina } \\
\hline \multicolumn{8}{|l|}{ Refineries } \\
\hline Fushun & 67.9 & 67.9 & 59.1 & 67.9 & 67.9 & 67.9 & 105.5 \\
\hline Daqing & 52.4 & 52.4 & 52.4 & 44.3 & 44.3 & 44.3 & 105.8 \\
\hline Jilin & 44.4 & 44.4 & 44.4 & 39.2 & 51.7 & 51.7 & 103.4 \\
\hline Jinxi & 40.6 & 40.6 & 41.3 & 48.0 & 48.0 & 48.0 & 100.4 \\
\hline Lanzhou & 40.6 & 40.6 & 40.6 & 77.6 & 77.6 & 77.6 & 90.0 \\
\hline Jinzhou & 41.4 & 41.4 & 36.9 & 46.5 & 48.0 & 48.0 & 104.7 \\
\hline Urumqi & 36.9 & 36.9 & 36.9 & 36.9 & 36.9 & 36.9 & 96.8 \\
\hline Others & 361.3 & 374.2 & 332.5 & 358.7 & 400.8 & 409.7 & 77.9 \\
\hline Total & 741.1 & 753.98 & 699.7 & 796.9 & 853.1 & 935.8 & $83.9 \%$ \\
\hline \multicolumn{8}{|l|}{ Sinopec } \\
\hline \multicolumn{8}{|l|}{ Refineries } \\
\hline Maoming & 95.8 & 95.8 & 95.8 & 95.8 & 95.85 & 95.85 & 103.7 \\
\hline Zhenhai & 67.4 & 85.2 & 85.2 & 142.0 & 142 & 142 & 88.5 \\
\hline Qilu & 74.5 & 74.5 & 74.5 & 74.5 & 74.55 & 74.55 & 100 \\
\hline Yanshan & 67.4 & 56.8 & 56.8 & 56.8 & 56.8 & 56.8 & 100 \\
\hline Guangzhou & 54.7 & 54.7 & 54.7 & 54.7 & 54.67 & 93.72 & 56.1 \\
\hline Gaoqiao & 51.8 & 51.8 & 51.8 & 78.1 & 78.1 & 78.1 & 84.5 \\
\hline Jinling & 49.7 & 74.5 & 74.5 & 92.3 & 92.3 & 92.3 & 83.1 \\
\hline Tianjin & 35.5 & 35.5 & 35.5 & - & - & - & - \\
\hline Yangzi & 39.0 & 39.0 & 39.0 & 56.8 & 56.8 & 56.8 & 98.7 \\
\hline Shanghai & 37.6 & 44.7 & 44.7 & 62.5 & 99.4 & 99.4 & 65 \\
\hline Changling & 35.5 & 35.5 & 35.5 & - & - & - & - \\
\hline Luovang & 35.5 & 35.5 & 35.5 & - & - & - & - \\
\hline Jingmen & 35.5 & 35.5 & 35.5 & - & - & - & - \\
\hline Others & 35.5 & 35.5 & - & 388.3 & 386.2 & 460.8 & - \\
\hline Total & 715.7 & 754.7 & 719.2 & 1101.9 & 1136.7 & 1250.3 & $83.1 \%$ \\
\hline
\end{tabular}

Notes: a) Converted using 7.1 barrels per ton for Chinese Crude and based on 365 day average (for PetroChina Data) All figures rounded to one decimal place

b) Refineries meeting the international capacity standard are highlighted. The international capacity standard is of the order of 10 million tons of crude per year equating to approximately 71 million barrels per year

c) Capacity Utilisation is estimated as: (crude throughput/refinery capacity)*100

Sources: Form 20-F Sinopec and PetroChina various years 
Table 2: Selected financial indicators of China's petrochemicals

\begin{tabular}{lrrrrrr}
\hline PetroChina & $\mathbf{1 9 9 8}$ & $\mathbf{1 9 9 9}$ & $\mathbf{2 0 0 0}$ & $\mathbf{2 0 0 4}$ & $\mathbf{2 0 0 5}$ & $\mathbf{2 0 0 6}$ \\
\hline Return on Sales (\%) & 14.4 & 19.8 & 33.2 & 38.1 & 35.1 & 28.9 \\
Profit/Employee ('000 Yuan) & 21.7 & 13.3 & 5.4 & 2.8 & 2.3 & 2.2 \\
Costs/Turnover (\%) & 77.2 & 73.3 & 65.2 & 62.0 & 65.2 & 71.3 \\
Employee Costs /Total Costs (\%) & 8.8 & 8.7 & 9.5 & 9.3 & 8.2 & 8.0 \\
Oil Cost/Total Costs (\%) & - & - & - & - & - & - \\
Self Supply (\%) & 97.8 & 95.8 & 93 & 84 & 89 & 82 \\
\hline Sinopec & & & & & & \\
\hline Return on Sales (\%) & -1.11 & 2.85 & 10.54 & 9.58 & 7.86 & 7.36 \\
Profit/Employee ('000 Yuan) & -0.004 & 0.013 & 0.068 & 0.153 & 0.177 & 0.232 \\
Costs/Turnover (\%) & 97.0 & 93.6 & 89.4 & 89.9 & 93.0 & 92.6 \\
Employee Costs/ Total Costs (\%) & 5.88 & 5.55 & 4.42 & 3.36 & 2.44 & 2.0 \\
Oil Cost/Total Costs (\%) & 69.8 & 71.6 & 76.9 & 79.4 & 85.2 & 86.8 \\
Self Supply (\%) & 34.7 & 30.4 & 25.3 & 20.5 & 20.2 & 20.4 \\
\hline
\end{tabular}

Sources: BP (2006); Form 20-F Sinopec and PetroChina various years.

Table 3: Major Sources of China’s Crude Oil in 2005

\begin{tabular}{lcc}
\hline Region of Origin & $\begin{array}{l}\text { Imports } \\
\text { (Million Tons) }\end{array}$ & $\begin{array}{l}\text { As \% of Total } \\
\text { Imports* }\end{array}$ \\
\hline Middle East & 67.4 & 40.4 \\
Asia Pacific & 30.3 & 18.2 \\
West Africa & 28.6 & 17.1 \\
Former Soviet Union & 19.6 & 11.7 \\
East \& Southern Africa & 6.7 & 4.0 \\
South \& Central America & 5.6 & 3.2 \\
Japan & 3.3 & 2.0 \\
North Africa & 3.2 & 1.9 \\
\hline
\end{tabular}

Note: *Total imports equal 166 million barrels.

Source: BP Statistical Review of World Energy Production (2006). 
Figure 1: China’s 0il consumption and production 1965-2005 ('000 bls/day)

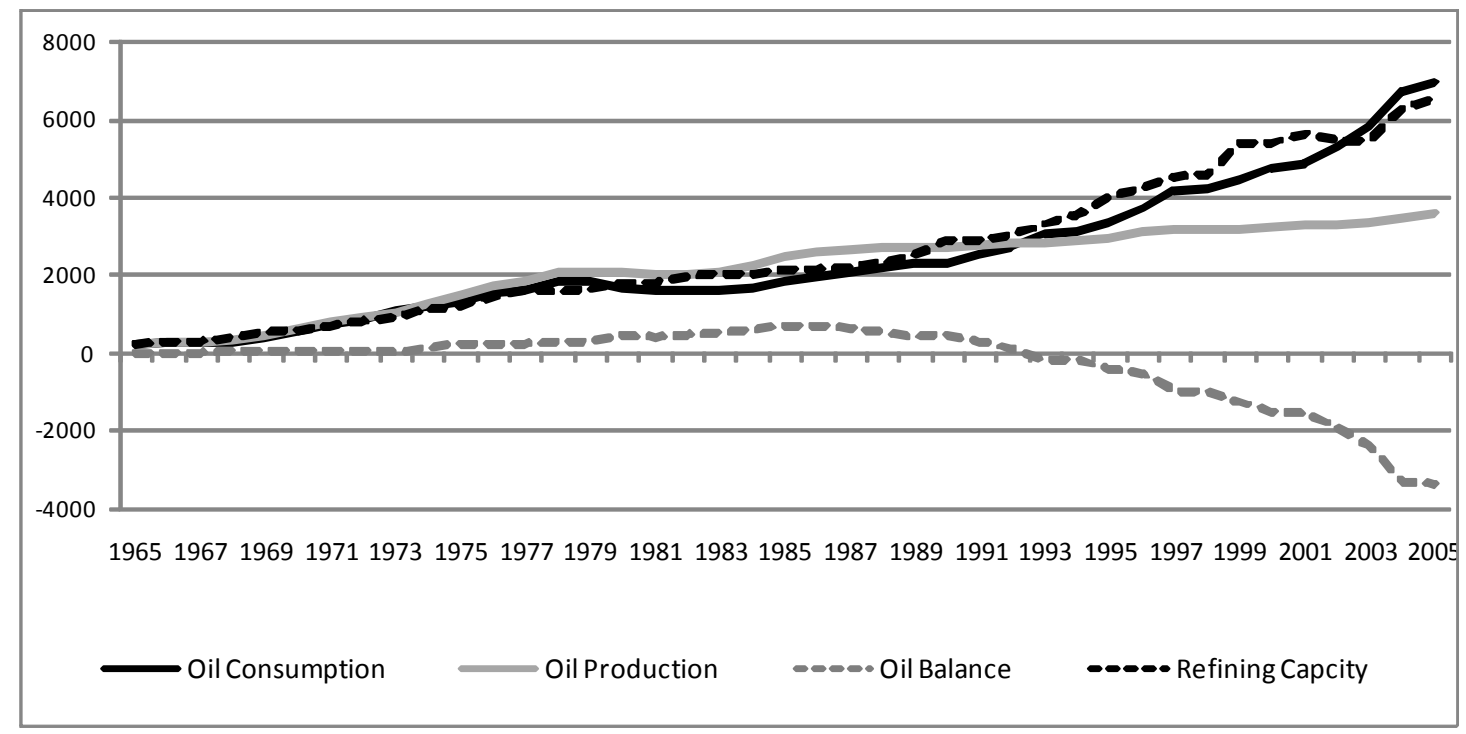

Source: BP Statistical Review of World Energy Production (2006).

Figure 2: Average real wages in China's oil sector vs. SOE average

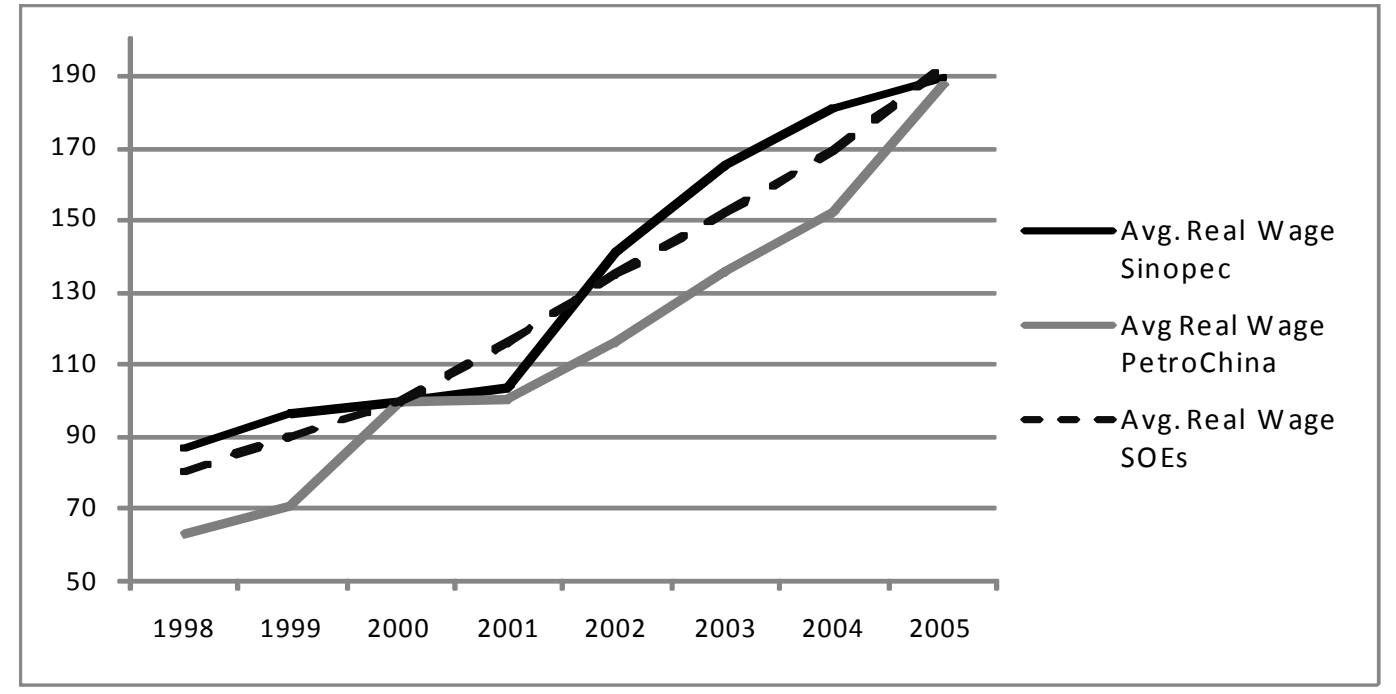

Notes: a) Average SOE wages from State Statistical Bureau. Average wages in Sinopec \& PetroChina estimated from data provided in 20-F and calculated as Total Employee Costs/Total Employees. b) Real wages calculated using Urban Price Index.

Source: State Statistical Bureau (Table 5.18), 20-F Sinopec \& PetroChina (2000-2006) 
Figure 3: Average Chinese and international crude oil prices (US\$)

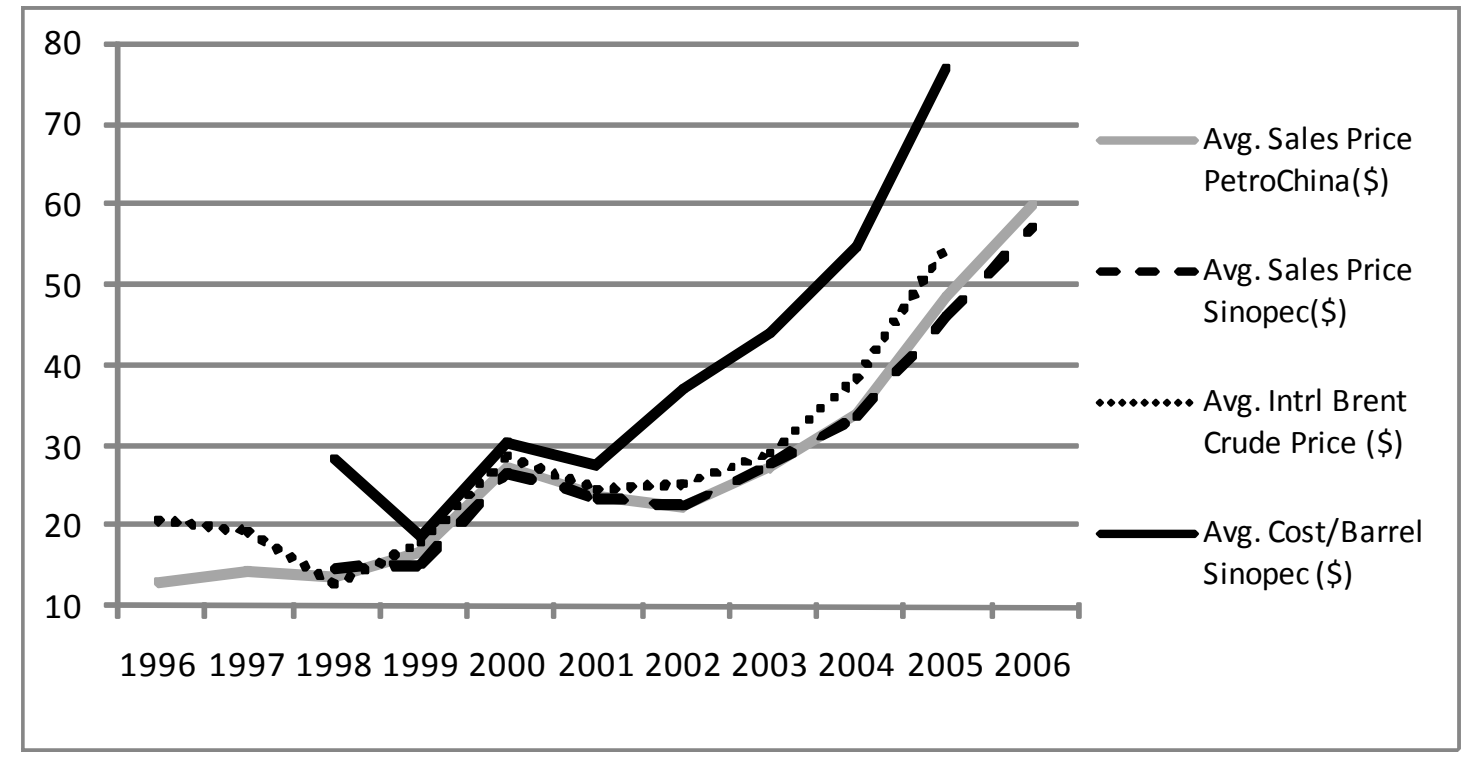

Notes: a) Average sales price sourced from company data. b) Average cost is estimated from Sinopec's total crude oil cost/barrels crude oil refined.

Sources: BP (2006); Form 20-F Sinopec and PetroChina various years. 